Available online at GSC Online Press Directory

GSC Biological and Pharmaceutical Sciences

e-ISSN: 2581-3250, CODEN (USA): GBPSC2

Journal homepage: https://www.gsconlinepress.com/journals/gscbps

(RESEARCH ARTICLE)

\title{
Antioxidant activities of aqueous extracts from two Thymus species growing in Turkey
}

\author{
Ozer Zuleyha* \\ University of Balikesir, Altinoluk Vocational School, Programme of Medicinal and Aromatical Plants, 10870 Altinoluk, \\ Edremit-Balikesir, Turkey.
}

Publication history: Received on 20 February 2020; revised on 07 March 2020; accepted on 09 March 2020

Article DOI: https://doi.org/10.30574/gscbps.2020.10.3.0045

\begin{abstract}
In this study, antioxidant activities of aqueous extracts from of Thymus longicaulis subsp. chaubardii (Rchb.f.) Jalas and T. longicaulis subsp. longicaulis C. presl were investigated. Infusion and decoction methods were used to prepare aqueous extracts. 1, 1-diphenyl-2-picrylhydrazyl (DPPH) free radical scavenging, $\beta$-carotene linoleic acid and CUPRAC methods were used to determined antioxidant activities. Aqueous extracts of species exhibited good antioxidant activity. Especially, higher antioxidant capacity was found in decoction extracts compared to infusion extracts for all methods.
\end{abstract}

Keywords: T. longicaulis subsp. chaubardii; T. longicaulis subsp. longicaulis; Antioxidant activity; Decoction; Infusion

\section{Introduction}

Lamiaceae (Labiatae) family has 300-400 endemic species which widely distributed worldwide in particular in the region of Mediterranean. Thymus species are a large genus belonging to the Lamiaceae family. Turkey has 39 species with 64 taxa. Among them 27 taxa are endemic [1-4]. Thymus species have uses in the pharmaceutical and food industries due to their antioxidant, antimicrobial, antibacterial, cytotoxic, antifungal, insecticidal and other biological activities of their essential oils. The essential oils were found to be rich in phenolic compounds, especially carvacrol [5-8]. These species are native to region of Marmara, Aegean and Black sea in Turkey and used as traditional medicine because of their biological properties. In Turkey, species of the genus Thymus L. is called as "Kekik".

Thymus species are known as source of phenolic compounds which have strong antioxidant activities [9]. Antioxidant compounds are polyphenolic structure and present as of almost all plants, fruits, vegetables, microorganisms, fungi an animal tissues. Antioxidants neutralize active oxygen formation or keeping the active oxygen which can damage the body. Phenolic compounds act as antioxidants and inhibition various diseases such as cancer, cardiovascular and neurodegenerative $[10,11]$. It is known that the different antioxidant compounds occur in plants. Natural antioxidants can occur in leaves, stem and seeds of plants [12-14].

There are few reports about chemical compounds and biological activities of various solvent extracts of T. zygioides Griseb [15], T. longicaulis subsp. chaoubardii [16], T. longicaulis subsp. chaoubardii var. chaoubardii [17], T. longicaulis C. Presl. subsp. longicaulis var. longicaulis and T. longicaulis C. Presl. subsp. longicaulis var. subisophyllus [5]. Thymus species have rich in essential oil content, dominated usually by thymol [18-21]. Azaz et al. [18] reported that thymol was the main component in the oils of T. longicaulis subsp. chaubardii var. chaubardii and T. zygioides var. lycaonicus. Sarikurkcu et al. [19] reported that $\gamma$-terpinene, thymol and $p$-cymene were identified as the predominant compounds

\footnotetext{
* Corresponding author: Ozer Zuleyha
} 
for T. longicaulis C. Presl subsp. longicaulis var. longicaulis. Also, Baser and Koyuncu [21] reported the main components of both varieties of T. longicaulis C. Presl. subsp. chaubardii was thymol.

Biological activities of diverse extracts and essential oils of Thymus species have previously been reported. However, to our best knowledge, there are no reports about the antioxidant capacity of aqueous extracts of T. longicaulis subsp. chaubardii (Rchb.f.) Jalas and T. longicaulis subsp. longicaulis C.presl (Figure 1).

In this study, we wish to report the antioxidant activities of aqueous extracts of T. longicaulis subsp. chaubardii (Rchb.f.) Jalas and T. longicaulis subsp. longicaulis C.presl. Antioxidant tests performed by three procedure systems.

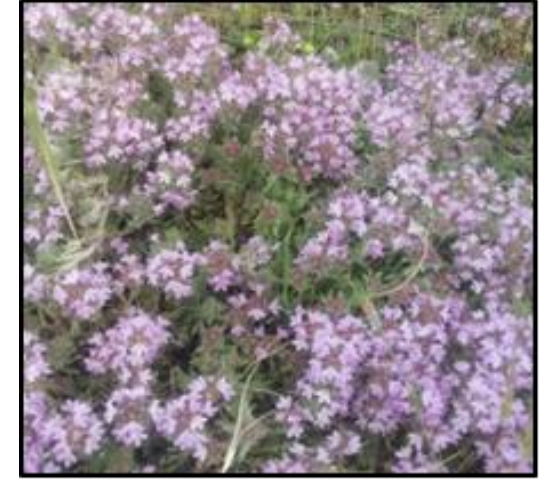

(a)



(b)

Figure 1 T. longicaulis subsp. chaubardii (a) and T. longicaulis subsp. longicaulis (b)

\section{Material and methods}

\subsection{Plant material}

Localities, altitude and collector numbers of the Thymus species are given in Table 1. The species were identified by Prof. Dr. Selami Selvi at Balikesir University. Voucher specimens were deposited at the Herbarium of Altinoluk Vocational School, Balikesir University, Balikesir, Turkey.

Table 1 List of the Thymus species.

\begin{tabular}{|c|c|c|c|c|c|c|}
\hline Code & $\begin{array}{l}\text { Collector } \\
\text { Number }\end{array}$ & Species & Locality & $\begin{array}{l}\text { Altitude } \\
\text { (m) }\end{array}$ & Coordinates & Year \\
\hline \multirow{2}{*}{$\mathrm{TC}$} & \multirow{2}{*}{ SV 1154} & \multirow{2}{*}{$\begin{array}{l}\text { Thymus longicaulis } \\
\text { subsp. chaubardii }\end{array}$} & \multirow{2}{*}{$\begin{array}{l}\text { Balikesir: Karanlıkdere } \\
\text { road edges and slopes }\end{array}$} & \multirow{2}{*}{1220} & N 3919521 & \multirow{2}{*}{2016} \\
\hline & & & & & E 2849145 & \\
\hline TL & SV 1150 & $\begin{array}{l}\text { Thymus longicaulis } \\
\text { subsp. longicaulis }\end{array}$ & $\begin{array}{l}\text { Balikesir: Bigadiç, Okçular } \\
\text { village, road edges and } \\
\text { slopes }\end{array}$ & 500 & $\begin{array}{l}\text { N } 391922 \\
\text { E } 281046\end{array}$ & 2016 \\
\hline
\end{tabular}

\subsection{Preparation of decoction and infusion samples}

$4 \mathrm{~g}$ of aerial parts of the plant, dried in the shade and chopped into small pieces.

For infusion; $2 \mathrm{~g}$ of the plant were added to $98 \mathrm{~mL}$ of distilled boiling water and allowed to stay for $15 \mathrm{minute}$.

For decoction; $2 \mathrm{~g}$ of the plant were added to $98 \mathrm{~mL}$ of distilled water and heated together in a steel kettle and allowed to stay for 15 minute after it boiled. The teas were filtered with an ashless filter paper. The filtrates were diluted with $25 \mathrm{~mL}$ of distilled water.

Aqueous extracts were kept at $-20^{\circ} \mathrm{Cuntil}$ they were used for antioxidant activity studies. 


\subsection{Antioxidant activity}

\subsection{1. $\beta$-carotene-linoleic acid}

The $\beta$-carotene-linoleic acid method was used analyzed antioxidant activity [9, 22-24]. $\beta$-carotene (0.5 mg) in $1 \mathrm{~mL}$ of chloroform was added to $25 \mu \mathrm{L}$ of linoleic acid, and $200 \mathrm{mg}$ of Tween 40 emulsifier mixture. After evaporation of chloroform under vacuum, $100 \mathrm{~mL}$ of distilled water saturated with oxygen, was through vigorous shaking. A mixture of four thousand microlitres was transferred into different test tubes containing different concentrations of the sample (10, 25, 50 and $100 \mu \mathrm{g} / \mathrm{mL})$. Butylated hydroxyanisole (BHA) and butylated hydroxytoluene (BHT) were used as standard compounds. IC 50 values of all samples were estimated.

\subsection{2. $D P P H$}

The free radical scavenging activity of the extracts was determined by the DPPH (1,1-diphenyl-2-picrylhydrazyl) assay $[9,22-25]$. In its radical form, DPPH absorbs at $517 \mathrm{~nm}$, but upon reduction by an antioxidant or a radical species its absorption decreases. Briefly, $0.1 \mathrm{mM}$ solution of DPPH in methanol was prepared and $160 \mu \mathrm{L}$ of this solution was added to $40 \mu \mathrm{L}$ of sample solutions in methanol at different concentrations $(10,25,50$ and $100 \mu \mathrm{g} / \mathrm{mL})$. These tubes were left in the dark for $30 \mathrm{~min}$. The measurements were made at $517 \mathrm{~nm}$. BHA and BHT were used as standard compounds. The potentials of samples on DPPH were determined and compared to the standards. IC 50 values of all samples were calculated. The reduction in absorbance shows the DPPH free radical scavenging of samples capability.

\subsubsection{CUPRAC}

The reducing capacities of extracts were evaluated using CUPRAC method [24, 26, 27]. Briefly, $1 \mathrm{mM}$ DMF, $10 \mathrm{mM}$ $\mathrm{CuCl}_{2}, 7,5 \mathrm{mM}$ Neocuproine, $1 \mathrm{M} \mathrm{NH}_{4} \mathrm{CH}_{3} \mathrm{COO}(\mathrm{pH} 7.0$ ) solution, and distilled water were mixed in volume ratio 1:1:1:0,6. After $180 \mathrm{ul}$ of the mixture was dispersed into the wells, $25 \mu \mathrm{L}$ diluted compounds (dilution ratio 1:20) in $\mathrm{EtOH}$. The samples were kept for $30 \mathrm{~min}$ at $25{ }^{\circ} \mathrm{C}$ The absorbance was measured at $450 \mathrm{~nm}$ against a reagent blank. Ethanol was used as a negative control. Curcumin was used as a positive control.

\subsection{Statistical analysis}

Antioxidant activity results evaluated by ANOVA test. (GraphPad, Software 8.3.0). P $<0.05$ was considered to be significant.

\section{Results and discussion}

In the DPPH and $\beta$-carotene linoleic acid methods, the activities were identified at $10,25,50$ and $100 \mu \mathrm{g} / \mathrm{mL}$ concentrations. BHA and BHT were used as standard compounds. The results are given as 50\% inhibition concentrations $\left(\mathrm{IC}_{50}\right)$ in Table 2 . Also, Inhibition $\%$ of DPPH and $\beta$-carotene linoleic acid methods are given in Figure 2.

DPPH method was used to evaluate the free radical scavenging efficacy of decoction and infusion of these species. The decoction of these species have good antioxidant activity for all tested methods. As seen in Table 2, among the studied species, decoction of $T$. longicaulis subsp. longicaulis determined a remarkable activity for $\beta$-carotene and DPPH assays, contrasted to BHA and BHT. Especially, T. longicaulis subsp. longicaulis decoction showed a salient DPPH activity. IC $\mathrm{C}_{50}$ value for the radical scavenging activity of T. longicaulis subsp. longicaulis decoction was found to be 9.51 $\mu \mathrm{g} / \mathrm{mL}$. Also, free radical scavenging activity of T. longicaulis subsp. longicaulis decoction was compored to those of BHA and BHT. In addition, IC50 values for BHA and BHT were found to be $13.40 \mu \mathrm{g} / \mathrm{mL}$ and $12.84 \mu \mathrm{g} / \mathrm{mL}$, respectively. These results showed that the free radical scavenging effect of T. longicaulis subsp. longicaulis decoction was higher than both of BHA and BHT. Lower IC 50 value exhibited higher radical scavenging effectiveness. IC 50 values for DPPH free radical scavenging activities for infusion of T. longicaulis subsp. longicaulis and T. longicaulis subsp. chaubardii and decoction of T. longicaulis subsp. chaubardii were found to be $12.01 \mu \mathrm{g} / \mathrm{mL}, 17.98 \mu \mathrm{g} / \mathrm{mL} \mathrm{and} 14.09 \mu \mathrm{g} / \mathrm{mL}$, respectively.

Decoction of T. longicaulis subsp. longicaulis showed great lipid peroxidation inhibition in the $\beta$-carotene-linoleic acid system $\left(\mathrm{IC}_{50}, 12.13 \mu \mathrm{g} / \mathrm{mL}\right)$. IC $\mathrm{C}_{50}$ values of BHA and BHT were found to be $12.23 \mu \mathrm{g} / \mathrm{mL} ; 8.57 \mu \mathrm{g} / \mathrm{mL}$ and $11.89 \mu \mathrm{g} / \mathrm{mL}$; $10.04 \mu \mathrm{g} / \mathrm{mL}$, respectively. None of the tested extracts exhibited high antioxidant activity than standards for the $\beta$ carotene-linoleic acid method. The lower inhibition value was found in infusion of T. longicaulis subsp. chaubardii 
( $\mathrm{IC}_{50} 28.85 \mu \mathrm{g} / \mathrm{mL}$ ). To bring about as a result, the weak activity estimated in these species is connect to a low amount of phenolics $[9,19,22,24,28]$.

$\mathrm{Cu}^{2+}$ reducing ability is commonly used to identified the reducing powers of curcumin and decoction and infusion of Thymus species (Figure 3). In CUPRAC method, same as other methods, decoction of Thymus species have better activity than the infusion as well as curcumin, which was used as a standard compound. $\mathrm{Cu}^{2+}$ reducing powers of the decoction of Thymus species decreased as follows: T. longicaulis subsp. chaubardii (1.42 $\left.\mathrm{mmol}^{\mathrm{TR}} \mathrm{g}^{-1}\right)$ and T. longicaulis subsp. longicaulis (1.40 mmol TR g-1).

As far as our literature survey could as certain, antioxidant activity of T. longicaulis subsp. longicaulis and T. longicaulis subsp. chaubardii decoctions and infusions have not previously been reported. In the literature, biological activities of various extracts of Thymus species have been reported. Kaska et al. [15] reported the phenolic content, antioxidant capacities, anthelmintic and cytotoxic activities of ethanol, methanol, acetone and water extracts of T. zygioides Griseb. On the other hand, antialzheimer, antidiabetic, antioxidant and antiobesity activities of ethanol extracts of T. zygioides var. lycaonius has previously been reported [29]. Also, antioxidant activity of hexane, ethyl acetate, methanol and water extracts of T. longicaulis subsp. longicaulis var. longicaulis were investigated [19]. Öztürk [5] reported total phenolic content and antioxidant activities of infusions, methanol and ethyl acetate extracts of T. longicaulis subsp. longicaulis var. longicaulis and T. longicaulis subsp. longicaulis var. subisophyllus. Additionally, Galasso et al. [30] reported the antioxidant, anti-inflammatory activities and phenolic compounds of T. longicaulis C. Presl hydroalcoholic extracts. According to this report, rosmarinic acid and methylapigenin rich extract, exhibited a strong antioxidant and anti-inflammatory effectiveness.

Table 2 Antioxidant activity of the Thymus species, BHA and BHT (IC $50 \mu \mathrm{g} / \mathrm{mL})$

\begin{tabular}{|c|c|c|c|c|c|}
\hline & & TC* & TL* $^{*}$ & BHA $^{* *}$ & BHT** \\
\hline \multirow{2}{*}{ DPPH } & Infusion & $17.98 \pm 3.01$ & $12.01 \pm 0.52$ & $10.56 \pm 0.63$ & $11.57 \pm 4.02$ \\
\hline & Decoction & $14.09 \pm 2.05$ & $9.51 \pm 1.24$ & $13.40 \pm 1.05$ & $12.84 \pm 1.62$ \\
\hline \multirow{2}{*}{$\begin{array}{l}\beta \text {-carotene } \\
\text { linoleic acid }\end{array}$} & Infusion & $28.85 \pm 10.18$ & $22.12 \pm 3.53$ & $12.23 \pm 1.44$ & $11.89 \pm 1.38$ \\
\hline & Decoction & $14.90 \pm 3.16$ & $12.13 \pm 0.96$ & $8.57 \pm 0.58$ & $10.04 \pm 0.78$ \\
\hline
\end{tabular}


Figure 2 Inhibition (\%) of DPPH and lipid peroxidation assays of the T. longicaulis subsp. longicaulis (decoction, TLD; infusion, TLI), T. longicaulis subsp. chaubardii (decoction, TCD; infusion, TCI), BHA and BHT. 


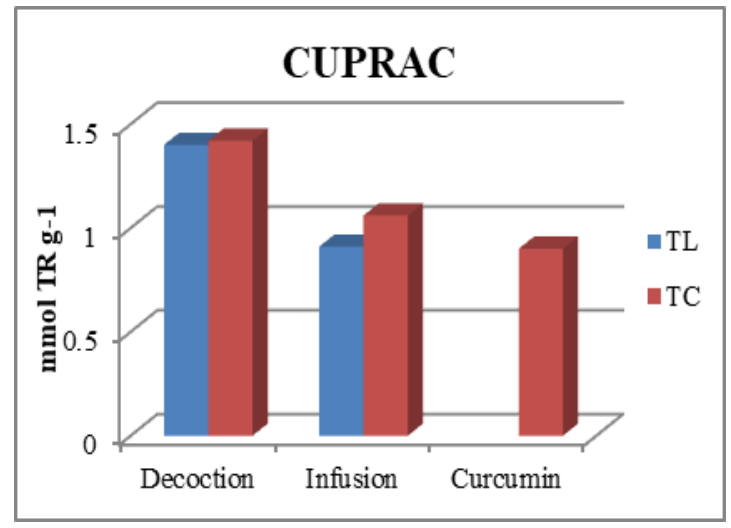

Figure 3 CUPRAC assay of the T. longicaulis subsp. chaubardii (TC), T. longicaulis subsp. longicaulis (TL) and curcumin.

\section{Conclusion}

In conclusion, we examined and reported the antioxidant activities of aqueous extracts of $T$. longicaulis subsp. chaubardii and T. longicaulis subsp. longicaulis in Turkey. Our results indicate clearly that aqueous extracts show strong antioxidant activity. Therefore decoction and infusion samples of these plants can be considered as a source of natural antioxidants. The results compared with the literature, the content of phenolic of decoction and infusion of the samples are an important factor for the antioxidant capacities. Antioxidant reduces physiological stress in organs and cells and prevents the formation and development of many diseases so it is important for nutrition. It was concluded that the decoction and infusion of these Thymus species can be used as an effective natural antioxidant in food and pharmaceutical industries.

\section{Compliance with ethical standards}

\section{Acknowledgments}

This study was presented at the "EurasianBioChem 2019" congress under the name "Antioxidant activities of decoction and infusion of Thymus longicaulis subsp. chaubardii and T. longicaulis subsp. longicaulis"and abstract published.

\section{Disclosure of conflict of interest}

There was no conflict of interest in this study.

\section{References}

[1] Başer KHC, Vural M, Tümen G, Akyalçın F and Satıl F. (1995). Two new records for the flora of Turkey. Turkish Journal of Botany, 19, 489-490.

[2] Başer KHC, Özek T, Kürkçüoğlu M and Duman H. (1997). Composition of the essential oil of Thymus subcollinus Klokov from Turkey. Journal of Essential Oil Research, 9, 105-106.

[3] Davis PH, Mill RR and Tan K. (1988). Flora of Turkey and the Aegean Islands, Edinburgh Univ. Press,10, 474.

[4] Jalas J. (1982). Thymus, Flora of Turkey and the East Aegean Islands: Davis P.H. (Ed.), Edinburgh Univ. Press, Edinburgh, 349-382.

[5] Öztürk N. (2015). Phenolic composition and antioxidant activity of the different extracts from Thymus longicaulis C Presl. subsp. longicaulis var. longicaulis and T. longicaulis C. Presl. subsp. longicaulis var. subisophyllus growing in Turkey. Pakistan Journal of Pharmaceutical Sciences, 28, 465-472.

[6] Ceylan 0 and Ugur A. (2015). Chemical composition and anti-biofilm activity of Thymus sipyleus BOISS. subsp. sipyleus BOISS. var. davisianus RONNIGER essential oil. Archives of Pharmacal Research, 38, 957-965. 
[7] Demirci F, Karaca N, Tekin M and Demirci B. (2018). Anti-inflammatory and antibacterial evaluation of Thymus sipyleus Boiss. subsp. sipyleus var. sipyleus essential oil Against rhinosinusitis pathogens. Microbial Pathogenesis, 122, 117-121.

[8] Tepe B, Sokmen M, Akpulat HA, Daferera D, Polissiou M and Sokmen A. (2005). Antioxidative activity of the essential oils of Thymus sipyleus subsp. sipyleus var. sipyleus and Thymus sipyleus subsp. sipyleus var. rosulans. Journal of Food Engineering, 66, 447-454.

[9] Özer Z. (2019). The phenolic compounds, antioxidant and anticholinesterase activities of Cyclotrichium origanıfolıum (Labıll.) Manden \& Scheng and Thymus sipyleus Boiss teas from Turkey, Studia Universitatis Babes-Bolyai Chemia, LXIV, 3, 217-228.

[10] Safaei-Ghomi J, Ebrahimabadi AH, Djafari-Bidgoli Z and Batooli H. (2009). GC/MS analysis and in vitro antioxidant activity of essential oil and methanol extracts of Thymus caramanicus Jalas and its main constituent carvacrol. Food Chemistry, 115, 1524-1528.

[11] Rice-Evans CA, Miller NJ and Paganga G. (1996). Structure-antioxidant activity relationships of favonoids and phenolic acids. Free Radical Biology and Medicine, 20, 933-956.

[12] Ahmad SU, Shuid AN and Isa NM. (2018). Antioxidant and anti-inflammatory activities of marantodes pumilum (blume) kuntze and their relationship with the phytochemical content. Records of Natural Products, $12,518$.

[13] Tian Z and Liu X. (2018). Chemical composition and antioxidant activity of the seeds oil of Vitex kwangsiensis C. Pei. Records of Natural Products, 12, 630-633.

[14] Phương DL, Thuy N, Long PQ, Quan PM, Thuy TTT, Minh PTH, Kauo PC and Thang T.D. (2018). Fatty acid, tocopherol, sterol compositions and antioxidant activity of three Garcinia seed oils. Records of Natural Products, 12, 323-331.

[15] Kaska A, Çiçek M, Deniz N and Mammadov R. (2018). Investigation of phenolic content, antioxidant capacities, anthelmintic and cytotoxic activities of Thymus zygioides Griseb. Journal of Pharmaceutical Research International, 21, 1-13.

[16] Tzakou O, Verykokidou E, Roussis V and Chinou I. (1998). Chemical composition and antibacterial properties of Thymus longicaulis subsp. chaoubardii oils: three chemotypes in the same population. Journal of Essential Oil Research, 10, 97-99.

[17] Dogan S and Dogan M. (2004). Determination of kinetic properties of polyphenol oxidase from Thymus (Thymus longicaulis subsp. chaubardii var. chaubardii. Food Chemistry, 88, 69-77.

[18] Azaz AD, Irtem HA, Kurkcuoglu M and Baser KHC. (2004). Composition and the in vitro anti-microbial activities of the essential oils of some Thymus species. Zeitschrift für Naturforschung C, 59, 75-80.

[19] Sarikurkcu C, Ozer M., Eskici M, Tepe B, Can Ş and Mete E. (2010). Essential oil composition and antioxidant activity of Thymus longicaulis C. Presl subsp. longicaulis var. longicaulis. Food and Chemical Toxicology, 48, 1801-1805.

[20] Başer KHC, Ozek T, Kirimer N and Tumen G. (1993). The occurrence of three chemotypes of Thymus longicaulis C Presl subsp longicaulis in the same population. Journal of Essential Oil Research, 5, 291-295.

[21] Başer KHC and Koyuncu M. (1994). Composition of the essential oils of two varieties of Thymus longicaulis C Presl subsp chaubardii (Boiss. et Heldr. ex Reichb. fil.) Jalas. Journal of Essential Oil Research, 6, 207-209.

[22] Ozer Z. (2018). Investigation of phenolic compounds and antioxidant activity of Mentha spicata subsp. spicata and M. longifolia subsp. typhoides (Briq.) Harley decoction and infusion. Journal of the Turkish Chemical Society, Section A, 5, 445-456.

[23] Miller HE. (1971). A Simplified Method for the Evaluation of Antioxidants. Journal of the American Oil Chemists' Society, 48, 91.

[24] Özer, Z., Gören AC., Kılıc T, Öncü M, Çarıkçı S and Dirmenci T. (2020). The phenolic contents, antioxidant and anticholinesterase activity of section Amaracus (Gled.) Vogel and Anatolicon Ietsw. of Origanum L. species. Arabian Journal of Chemistry.

[25] Blois MS. (1958). Antioxidant determinations by the use of a stable free radical. Nature, 181, 1199-2000.

[26] Apak R, Güçlü K, Özyürek M and Karademir SE. (2008). Mechanism of antioxidant capacity assays and the CUPRAC (cupric ion reducing antioxidant capacity) assay. Microchimica Acta, 160, 413-419. 
[27] Apak R. (2019). Current issues in antioxidant measurement. Journal of Agricultural and Food Chemistry, 67, 9187-9202.

[28] Ustuner O, Anlas C, Bakirel T, Ustun-Alkan F, Diren Sigirci B, Ak S and Koca-Caliskan U. (2019). In vitro evaluation of antioxidant, anti-inflammatory, antimicrobial and wound healing potential of Thymus sipyleus Boiss. subsp. rosulans (Borbas) Jalas. Molecules, 24, 3353.

[29] Ekin HN, Orhan DD, Orhan IE, Orhan N and Aslan M. (2019). Evaluation of enzyme inhibitory and antioxidant activity of some Lamiaceae plants. Journal of Reserach in Pharmacy, 23, 749-758.

[30] Galasso S, Pacifico S, Kretschmer N, Pan SP, Marciano S, Piccolella S and Bauer R. (2014). Influence of seasonal variation on Thymus longicaulis C. Presl chemical composition and its antioxidant and anti-inflammatory properties. Phytochemistry, 107, 80-90.

\section{How to cite this article}

Ozer Z. (2020). Antioxidant activities of aqueous extracts from two Thymus species growing in Turkey. GSC Biological and Pharmaceutical Sciences, 10(3), 16-22. 